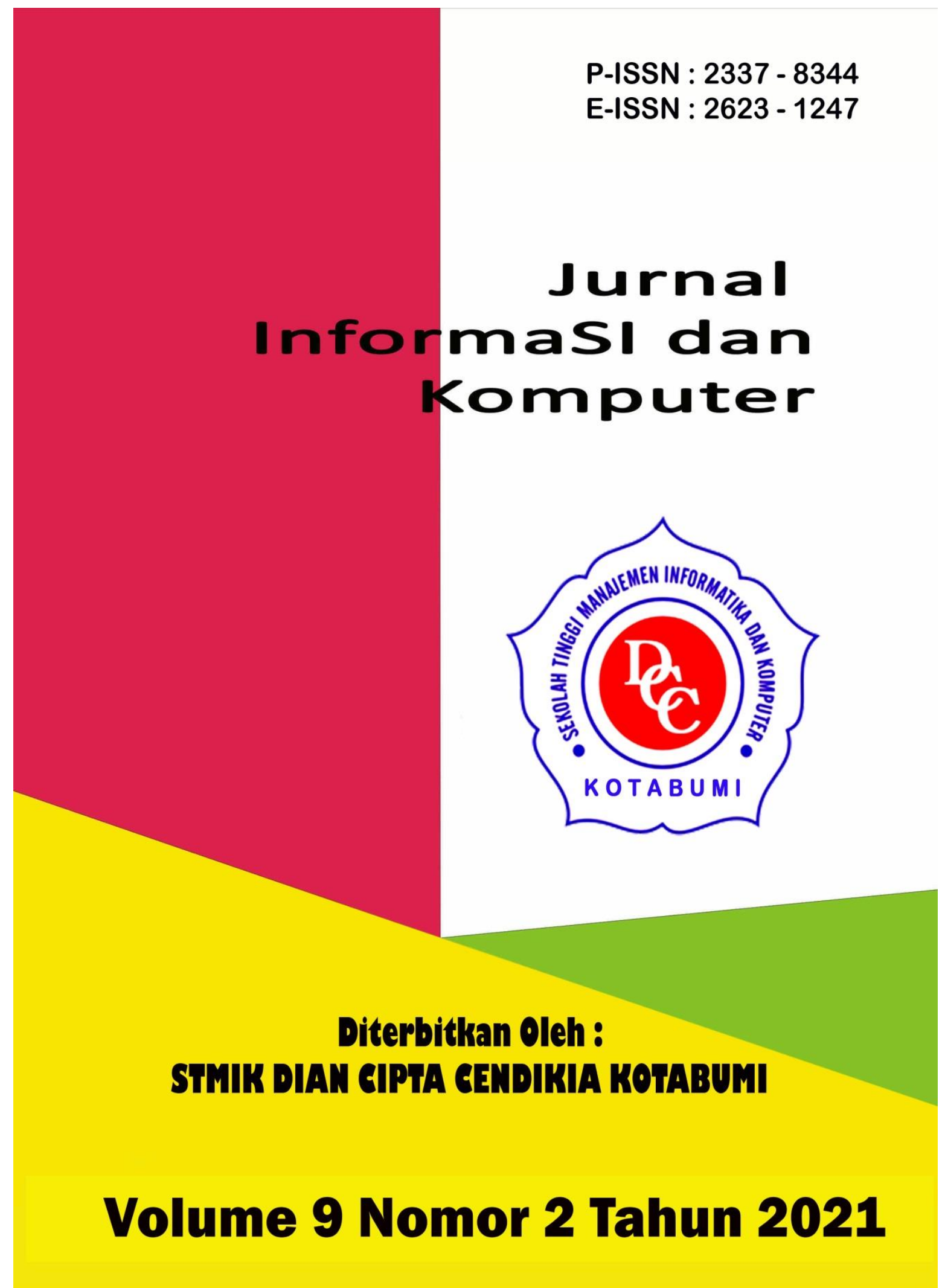




\section{Penerbit}

\section{Lembaga Penelitian STMIK Dian Cipta Cendikia Kotabumi}

Hak atas naskahh/tulisan tetap berada pada penulis, isi diluar tangung jawab penerbit dan Dewan Penyunting 


\section{PENGANTAR REDAKSI}

Puji syukur dipanjatkan kehadirat Tuhan Yang Maha Esa, atas karunia dan limpahan rahmatNYA jualah Jurnal Informasi dan komputer (JIK) STMIK Dian Cipta Cendikia Kotabumi ini dapat terwujud.Jurnal Informasi dan Komputer (JIK) yang terbit dua (2) kali dalam setahun ini merupakan suatu wadah untuk penyebar luasan hasil-hasil penelitian, studi pustaka, karya ilmiah yang berkaitan dengan Informasi dan Komputer khususnya bagi dosen-dosen STMIK Dian Cipta Cendikia Kotabumi serta umumnya para cendikiawan, praktisi, peneliti ilmu Informatika dan Komputer.

Harapan, dengan diterbitkannya Jurnal Informasi dan Komputer (JIK) ini sebagai salah satu bentuk sumbangan pemikiran dalam pengembangan ilmu informatika dan komputer yang berkaitan dengan kajian-kajian di bidang tekhnologi Informatik, Komunikasi Data dan Jaringan Komputer, perancangan dan Rekayasa Perangkat Lunak, serta ilmu-ilmu yang terkait dengan bidang Informasi dan Komputer lainnya.

Berkenaan dengan harapan tersebut, kepada para peneliti, dosen dan praktisi yang memiliki hasil-hasil penelitian, kajian pustaka, karya ilmiah dalam bidang tersebut diatas, dengan bangga redaksi Jurnal Informasi dan Komputer (JIK) menerima naskah ringkasan untuk dimuat pada jurnal Informasi dan Komputer (JIK) STMIK Dian Cipta Cendikia Kotabumi dengan berpedoman pada penulisan naskah jurnal sebagaimana dilampirkan pada halaman belakang (Bagian kulit dalam) buku jurnal ini.

Mutu dari suatu jurnal ilmiah tidak hanya ditentukan oleh para pengelolanya saja, tetapi para penulis dan pembaca jualah yang mempunyai peranan besar dalam meningkatkan mutu jurnal Informatika dan Komputer ini. Merujuk pada realita ini kamu sangat mengharapkan peran aktif dari peneliti untuk bersama-sama menjaga dan memelihara keberlangsungan dari jurnal Informasi dan Komputer STMIK Dian Cipta Cendikia Kotabumi ini. Yang juga tidak kalah pentingnya dari partisipasi tersebut diatas, adalah saran dan kritik yang membangun dari pembaca yang budiman agar kiranya dapat disampaikan langsung kepada redaksi JIK. Saran dan kritik yang membangun akan dijadikan masukan dan pertimbangan yang sangat berarti guna peningkatan mutu dan kualitas Jurnal Informasi dan Komputer STMIK Dian Cipta Cendikia Kotabumi.

Tak lupa diucapkan terima kasih yang tak terhingga atas perhatian dan kerjasama dari semua pihak yang tak dapat disebutkan satu persatu hingga dapat diterbitkan nya Jurnal Informasi dan Komputer (JIK) STMIK Dian Cipta Cendikia Kotabumi. Semoga apa yang telah diperbuat untuk kebaikan akan menjadi amal ibadah, amin.

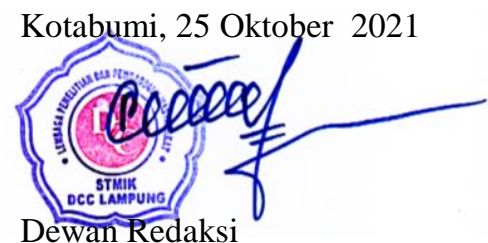




\section{JURNAL INFORMASI DAN KOMPUTER}

Volume 9 Nomor 2 Oktober 2021

Jurnal Informasi dan Komputer merupakan Sarana informasi ilmu pengetahuan, Tekhnologi dan Komunikasi yang berupa hasil penelitian, tulisan ilmiah, Ataupun studi pustaka. Jurnal ini terbit dua kali setahun pada bulan April dan Oktober. Berisi hasil penelitian ilmiah di bidang informatika yang bertujuan untuk menghubungkan adanya kesenjangan antar kemajuan teknologi dan hasil penelitian. Jurnal ini di terbitkan pertama kali pada tahun 2013.

Penanggung Jawab:

Ketua STMIK Dian Cipta Cendikia Kotabumi

\section{Pembina:}

Ketua STMIK Dian Cipta Cendikia Kotabumi Ketua Lembaga Penelitian STMIK Dian Cipta Cendikia Kotabumi

\section{Pimpinan Redaksi}

Dwi Marisa Efendi,.S.Kom.,M.Ti

\section{Redaksi pelaksana}

Rustam,.S.Kom,.M.Ti (STMIK Dian Cipta Cendikia Kotabumi)

Nurmayanti M.Kom (STMIK Dian Cipta Cendikia Kotabumi)

Sukatmi,.S.Kom., M.Kom (AMIK DCC Bandar Lampung)

Sampurna Dadi Riskiono,M.Kom (Universitas Teknokrat Indonesia)

Ifo Wahyu Pratama,S.Kom.,M.Ti(AMIK MASTER Lampung)

\section{Mitra Bestari}

Dr. RZ. ABDUL AZIZ, ST., MT (Institut Informatika dan Bisnis Darmajaya)

Dr. Dadang Sudrajat, S.Si, M.Kom (STMIK IKMI Cirebon)

Dr. Septafiansyah Dwi Putra, S.T., M.T (Politeknik Negeri Lampung)

Dr. Evi Grativiani, S.E., M.S.I (Universitas Sebelas Maret)

Rohmat Indra Borman ( Universitas Teknokrat Indonesia )

Ferry Wongso, S.KOm., M.Kom ( STMIK Darma Pala Riau)

Ferly Ardhy, S.Kom., M.Ti ( Universitas Aisyah Pringsewu )

Firmansyah, S.E., M.Si (STMIK Darma Pala Riau)
Amarudin (Universitas Teknokrat Indonesia)

Didi Susianto, S.T., M.Kom (AMIK Dian Cipta Cendika Bandar Lampung)

Alhibarsyah, St., M.Kom (STMIK Tunas

Bangsa Bandar Lampung)

Kemal Farouq Mauladi, S.Kom .M.Kom (Universitas Islam Lamongan)

Rima Mawarni, M.Kom ( STMIK Dian Cipta Cendikia Kotabumi)

Wira Jaya Hartono, S.Pd., M.Pd ( STMIK Darma Pala Riau)

Penerbit : STMIK Dian Cipta Cendikia Kotabumi Bekerja Sama Dengan LPPM STMIK Dian Cipta Cendikia Kotabumi.

\section{Alamat Redaksi/Penerbit:}

Jl. Negara No. 3 Candimas Kotabumi Lampung Utara

No Telpon/Fax 072423003

Email : 1ppm-stmik@dcc.ac.id 


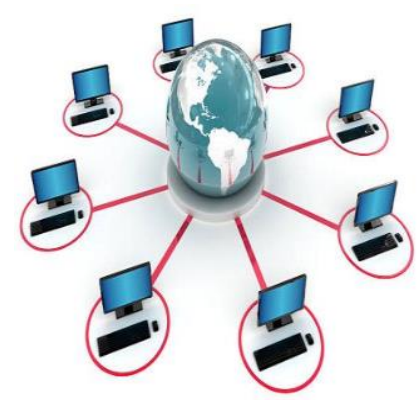

\section{JURNAL INFORMASI DAN KOMPUTER VOL. 9 NO. 2 THN. 2021}

\section{DAFTAR ISI}

Halaman

Sistem Informasi Akuntansi Persedian Barang Berbasis Web Pada Lembaga

Permasyarakatan Kelas II A Banceuy Bandung : "Kelompok Tani Desa Banjar Kertarahayu" Teuku Rian Hardiyansyah, Fatia Salsa Azzahra (Politeknik Piksi Ganesha Bandung ${ }^{1,2}$ )

Penerapan Finite State Automata Pada Vending Machine Penjual Obat Non Resep

Dokter Dan Keperluan Medis

Eko Supriyanto $^{1}$, Angga Ardiansyah ${ }^{2}$, Frieyadie $^{3}$, Sri Rahayu ${ }^{4}$, Windu Gata ${ }^{5}$

(Universitas Nusa Mandiri ${ }^{12}$ )

Sistem Pendukung Keputusan Untuk Menentukan Kelayakan Pengajuan Sertifikasi Guru Dengan Metode Simple Additive Weighting (Studi Kasus : Ma Al Muhajirin Janti Jogoroto Jombang)

Budiman, umam baharudin, winarti

(Universitas Darul 'Ulum Jombang)

Perancangan Infrastruktur Domain Name Server Lokal Menggunakan Ubuntu Server 16.04

Pada PT. Xyz

Zaenal Mutaqin Subekti, Hendra Setiawan, Satria, Widia Murni Wijaya,

Aliy Hafiz, Warsudi

(STMIK Bani Saleh, Universitas Negeri Yogyakarta, AMIK Dian Cipta Cendikia,

STMIK MIC CIkarang)

Perancangan Sistem Informasi Idea Proposal (Ip) Berbasis Web Pada Pt. Paxel Algorita Unggul

Julian Murhan Sahputra, Indah Purnamasari

(Universitas Nusa Mandiri ${ }^{12}$ )

Sistem Pendukung Keputusan Untuk Menentukan Ekstrakurikuler Atletik

Berdasarkan Bakat Siswa Menggunakan Metode Profile Matching

Agnes Basuki, Petrus Sokibi, Tiara Eka Putri

(Universitas Catur Insan Cendekia)

Penerapan Algoritma K-Means Untuk Pengelompokan Usia Calon Penerima Vaksin

Di Kab. Ngawi

Irna Yuniarfi, Saifulloh

(Universitas PGRI Madiun ${ }^{12}$ )

System Penilaian Seleksi Calon Karyawan Baru Menggunakan Metode Simple Additive Weighting (SAW) Di PT.TNA

Anik Sri Wahyuningsih, Yudhi Firmansyah

(Universitas Panca Sakti Bekasi ) 
Perancangan Sistem Informasi Pembayaran SPP Menggunakan Framework Laravel Ichwan Habib Moudi

(Universitas Panca Sakti Bekasi)

Implementasi Algoritma K-Means Dan Algoritma Apriori Optimasi Kinerja Ecu

(Study Kasus Mobil Avanza Dan Xenia)

Sigit Mintoro' Asep Afandi

(STMIK Dian Cipta Cendikia Kotabumi)

Sistem Pakar Penyakit Buah Kakao Untuk Peningkatan Hasil Panen Kakao Menggunakan

Metode Case Base Reasoning (CBR) Berbasis Web Mobile

Aliy hafiz, Verawati

(AMIK Dian Cipta Cendikia,Bandar Lampung)

Penerapan Metode Rapid Application Develomment (RAD) Dalam Pengembangan

Sistem Pemesanan Menu Berbasis Android

Aris Baihaqi, Tumini

(Fakultas Sains dan Teknologi ${ }^{1,2}$ )

Rancang Bangun Sistem Informasi Geografis Pariwisata Di Lampung Timur

Sukatmi, Rexa Alfa Rizi

(AMIK DCC Bandar Lampung ${ }^{12}$ )

Implementasi Psak No. 45 Pada Proses Penyusunan Laporan Keuangan Menggunakan

M.S. Excel Dan Aplikasi Accurate Accouting Pada STMIK Bani Saleh

Marhakim, Willy Adam

(STMIK Bani Saleh ${ }^{12}$ )

Sistem Prediksi Harga KOPI LAMBAR ( Lampung Barat) Dengan Metode

Backpropagation, dan Double Exponential ( Studi Kasus BUMDES )

Supriyanto, Dwi marisa Efendi,Rhomadhon

(STMIK Dian Cipta cendikia Kotabumi ${ }^{1-}$ )

Sistem Informasi Pemasaran Produk Umkm Berbasis Web Pada Kecamatan Bumi

Nabung Lampung Tengah

Yuli Syafitri, Agus Prasetyo, Reni Astika

(AMIK Dian Cipta Cendikia Bandar Lampung)

Rancang Bangun Aplikasi Pembelajaran Aksara Lampung Berbasis Android

Ferly Ardhy, Hendra Syahrobi

(Universitas Aisyah Pringewu ${ }^{1,}$ STMIK Dian Cipta Cendikia ${ }^{2}$ )

Sistem Pakar Diagnosa Penyakit Kulit Pada Balita Menggunakan Metode Naïve

Bayes Dan Forward Chaining Studi Kasus Puskesmas Cempaka Sungkai Selatan

Sidik Rahmatullah, Rima Mawarni

(STMIK Dian Cipta Cendikia Kotabumi ${ }^{12}$ )

Rekayasa Perangkat Lunak Perhitungan Harga Pokok Produksi Metode

Full Costing Pada Umkm Mitra Cake Di Bandar Lampung

Pitrawati, Arif Sanjaya

(AMIK Dian Cipta Cendikia, Bandar Lampung) 
Rancang Bangun Sistem Ujian Online Menggunakan Algoritma Cosine Similarity

Berbasis Web

Haryono, Zaenal Mutaqin Subekti, Widiyawati, Hidayatullah

(STMIK Bani Saleh ${ }^{1234}$ )

Model Aplikasi Helpdesk Ticketing System Berbasis Web Menggunakan Metode Rad

Indra Permana

Pattern Recognition Tulisan Tangan Huruf Hijaiyah Menggunakan Metode

Convolutional Neural Network (CNN)

Mufassiril Abror, Nopiyanto

(Universitas Panca Sakti Bekasi ${ }^{12}$ )

Aplikasi Sistem Informasi Keuangan Berbasis Android Di Perumahan Taman

Karang Bahagia

Melda Ayulestari

(Universitas Panca Sakti Bekasi)

Audit Pelayanan Sistem Rujukan Online Puskesmas Menggunakan Framework COBIT 5.0

Nurmayanti, Merri Parida, Ngajiyanto, Ina Anzalna

(STMIK Dian Cipta Cendikia Kotabumi ${ }^{1234}$ )

Perancangan Sistem Informasi Pengolahan Data Nilai Siswa Berbasis Web

Erin Ermawati, Anik Sri Wahyuningsih

(Fakultas Sain dan Teknologi, Universitas Panca Sakti Bekasi ${ }^{12}$ )

Pengembangan Sistem Pelaporan Data Hasil Inspeksi Barang Berbasis Web

Siska Putriani

(Universitas Pancasakti Bekasi)

Penerapan Extreme Programming Dalam Perancangan Aplikasi Web Food Market

Tumini, Hilman Septiana

(Fakultas Sains dan Teknologi Universitas Panca Sakti Bekasi ${ }^{1,2}$ )

Sistem Pencarian Barang Berbasis Website Menggunakan Php Dan Mysql

Studi Kasus PT. Surya Technology Industri Sulaeman

(Universitas Panca Sakti Bekasi)

Implementasi Metode Prototype Pada Sistem Peminjaman Alat Kerja Berbasis Web

Di PT SK Metalindo

Ali Mulyanto, Arjun Gunawan

(Univeritas Panca Sakti Bekasi)

Aplikasi Tata Cara Wudhu Menggunakan Teknologi Augmented Reality

Sebagai Media Pembelajaran Di TK Al Fatih

Ahmad Yakub , Idarul Fadli

(Universitas Panca Sakti Bekasi ${ }^{12}$ )

Sistem Pakar Diagnosa Penyakit Ayam Petelur Menggunakan Metode Certainty Factor

Berbasis Web Mochammad

Taufiq Hidayat, Ali Mulyanto

(Universitas Panca Sakti Bekasi ${ }^{12}$ ) 
Penerapan Metode Prototyping Dalam Perhitungan Hasil Produksi Menggunakan

Arduino Uno R3 Dan Php Di PT. Indonesia Epson Industry

Amandha Aulia, Ajar Rohmanu

(Universitas Panca Sakti Bekasi ${ }^{12}$ )

System Pendukung Keputusan Penentuan Guru Teladan Dengan Metode Profile Matching

Hasbulloh, Agmawarnida

(Universitas Panca Sakti Bekasi ${ }^{1,2}$ )

Implementasi Waterfall Method Pada Aplikasi Buku Induk Siswa Berbasis Web

Idam Holid, Yogie Krisnayadi

(Universitas Panca Sakti ${ }^{12}$ )

Pengembangan Text To Speech Media Pembelajaran Untuk Pengenalan

Anggota Tubuh Manusia Kelas V Sekolah Dasar

Juwanda Saputra, Ali Mulianto

(Teknik Infomratika Fakulutas Sains dan Teknologi ${ }^{12}$ )

Perancangan Sistem Peminjaman Barang Berupa Aset Tetap Berbasis Web

Pada Lembaga Permasyarakatan Kelas II A Banceuy Bandung

Guntur Salasa Priambodo, Perwito, Candra Mecca Sufyana

(Politeknik Piksi Ganesha Bandung ${ }^{1,2,3}$ )

Metode Pemilihan Karyawan Terbaik Sebagai Penentu Goodwill Perguruan Tinggi

Dengan Menggunakan Metode Topsis (Studi Kasus Perguruan Tinggi Di Lampung Utara)

Dwi Sartika, Pakarti Riswanto

(STMIK Dian Cipta Cendikia Kotabumi)

Sistem Pendukung Keputusan Pemilihan Merek Smartphone Menggunakan

Metode Analytical Hierarchy Process (AHP)

Ade Kiki Fatmawati, Muhammad Sultan Raflie, Norma Yunita

(Universitas Nusa Mandiri ${ }^{123}$ )

Pattern Recognition Aksara Lampung Menggunakan Algoritma Neural Network

Metode Analytical Hierarchy Process (AHP)

Nopiyanto, Rahmadi

(Universitas Panca Sakti Bekasi) 


\title{
IMPLEMENTASI WATERFALL METHOD PADA APLIKASI BUKU INDUK SISWA BERBASIS WEB
}

\author{
Idam Holid ${ }^{1}$, Yogie Krisnayadi ${ }^{2}$ \\ Universitas Panca Sakti ${ }^{12}$ \\ Kampus C J1. Kapten Sumantri No 16 Cikarang, kab. Bekasi 17530 \\ E-mail : idamholid1996@gmail.com ${ }^{1}$,yogiekrisnayadi@gmail.com ${ }^{2}$
}

\begin{abstract}
ABSTRAK
Pengelolaan data di dalam Buku Induk Siswa merupakan suatu hal yang sangat penting bagi setiap sekolah karena menunjang kelancaran dalam memberikan informasi. Buku Induk Siswa juga merupakan bagian penting dan termasuk kedalam elemen penunjang akreditasi sebuah sekolah. Banyak sekolah yang masih mengelola Buku Induk Siswa secara manual dan tidak efektif. Dalam hal ini dikarenakan sistem administrasi pendidikan yang ada disetiap sekolah masih menggunakan metode administrasi data belum terkomputerisasi. Buku Induk Siswa membutuhkan pengerjaan yang lama karena staff atau guru harus menualis secara manual, Buku Induk Siswa juga rentan rusak dan hilang. Oleh karena itu tujuan penelitian ini adalah membangun sebuah Aplikasi Buku Induk Siswa Berbasis Web yang diharapkan dapat membantu staff tata usaha, guru dan siswa. Metode penelitian yang penyusun buat dengan menggunakan metide deskriptif yang menggambarkan suatu keadaan atau permasalahan yang sedang terjadi berdasarkan fakta dan data-data yang diperoleh dan dikumpulkan pada saat melakukan penelitian. Metode waterfall diimplementasikan dalam membangun aplikasi supaya aplikasi yang dihasilkan lebih baik dan berkualitas. Berdasarkan pada hasil pembahasan dan kesimpulan yang dilakukan terhadap Aplikasi Buku Induk Siswa Berbasis Web dengan framework Laravel, bahwa aplikasi buku induk siswa sudah dibuat dan dapat digunakan serta dapat membantu sekolah dalam pengelolaan data buku induk siswa bagi guru serta kemudahan akses informasi siswa dan orang tua atau wali murid.
\end{abstract}

Kata kunci : Aplikasi, Buku Induk siswa, Metode Waterfall, framework Laravel.

\begin{abstract}
S
Data management in the Student Master Book is very important for every school because it supports the fluency in providing information. The Student Master Book is also an important part and is included in the supporting elements of a school's accreditation. Many schools still manage the Student Master Book manually and ineffectively. In this case, because the education administration system that exists in each school is still using the data administration method that has not been computerized. The Student Master Book requires a long time to work because the staff or teacher must write it manually, the Student Master Book is also vulnerable to damage and loss. Therefore, the purpose of this research is to build a WebBased Student Master Book Application which is expected to help administrative staff, teachers and students. The research method that the authors made using a descriptive method that describes a situation or problem that is currently happening based on the facts and data obtained and collected at the time of conducting the research. The waterfall method is implemented in building applications so that the resulting applications are better and of higher quality. Based on the results of the discussion and conclusions made to the Web-Based Student Master Book Application with the Laravel framework, that the student master book application has been created and can be used and can help schools in managing student master book data for teachers and easy access to student information and parents or student Guardian.
\end{abstract}

Key word: Aplikasi, Buku Induk siswa, Metode Waterfall, framework Laravel.

1. PENDAHULUAN
Teknologi informasi berkembang seiring dengan meningkatnya kebutuhan masyarakat. Dalam 
memasuki dunia globalisasi, masyarakat mengenal teknologi semakin maju untuk mempermudah melakukan berbagai kegiatan dalam kehidupan. Kemajuan dibidang transportasi, komunikasi, kesehatan, pendidikan dan bidang lainnya merupakan contoh-contoh bahwa masyarakat semakin memerlukan teknologi dalam kehidupan ini.

Mengingat akan pesatnya kemajuan teknologi yang sudah merambah kesemua bidang, serta pola kehidupan masyarakat yang sudah relatif maju. Sistem informasi yang berbasis web dapat dimanfaatkan sebagai sarana peningkatan informasi. Pemanfaatan tersebut akan mempermudah suatu pekerjaan seperti dalam pengolahan data lebih cepat, keputusan yang diambil lebih tepat, menghemat biaya dan waktu. Disamping itu juga pemanfaatan teknologi seluler dengan berbagai aplikasi dan layanannya.

Penggunaan Sistem Website Framework Laravel sebagai media penyampaian data sekarang sudah banyak dilakukan oleh instansi-instansi untuk menunjang kinerja mereka dalam menginformasikan data. Salah satunya dengan menggunakan Website Framework Laravel. Banyak instansi-instansi terutama sekolah yang menggunakan Website sebagai media penyampai informasi. Dengan menggunakan Website Framework Laravel menginformasikan data akan lebih cepat dan data yang diberikanakan lebih akurat.

Sekolah Dasar Islam Terpadu (SDIT) INSAN KAMIL merupakan salah satu sekolah yang belum memiliki sistem informasi berbasis komputer. Terutama pengelolaan administrasi dan informasi data siswa. Informasi yang dimuat masih menggunakan sistem yang manual sehingga memerlukan tempat, biaya yang besar dan rentan rusak serta hilang. Dengan pengolahan data yang masih manual terkadang staff administrasi Tata Usaha (TU) Sekolah terlambat dalam memberikan informasi sehingga penyampaian pelayanan administrasi sekolah tidak efektif.

Pada setiap tahunnya jumlah siswa SDIT Insan Kamil terus bertambah, pendataan pada Buku Induk siswa juga bertambah. Hal tersebut membuat staff tata usaha sekolah bertambah beban kerjanya, terlebih buku induk dengan format kurikulum tahun 2013 yang sangat komplek. Pengerjaan penulisan buku induk menjadi sangat lama dan terhambat. Selain itu buku induk yang manual rentan rusak dan hilang serta memerlukan tempat dan biaya yang cukup besar. Proses penulisan buku induk siswa secara manual juga memerlukan keterampilan tulisan tangan yang baik serta rapih dan hal tersebut tentunya tidak dimiliki setiap orang. Perubahan data siswa dinamis setiap tahun berubah, buku induk yang manual kurang fleksibel dalam hal update dan upgrade data, ketika terjadi kesalahan dalam hal pengisian data banyak coretan yang tidak perlu sehingga membuat buku induk terkesan tidak rapih.

Dengan adanya sistem informasi buku induk berbasis web akan lebih memudahkan staff administrasi Tata Usaha (TU) Sekolah dalam pengerjaan pendataan buku induk siswa serta penyimapan data siswa yang lebih aman dan rapih. Berdasarkan latar belakang diatas maka dibutuhkanlah sebuah sistem terkomputerisasi dengan aplikasi yang mobile dan sederhana agar pengelolaan Buku Induk Siswa tidak dilakukan secara manual.

Metode yang digunakan untuk membuat pengembangan sistem adalah metode waterfall. Konsep dasar dari metode waterfall ini adalah "Linear Sequential Model", dimana hal ini menggambarkan pendekatan yang sistematis dan juga berurutan pada pengembangan perangkat lunak, dimulai dengan spesifikasi kebutuhan pengguna lalu berlanjut melalui tahapan-tahapan perencanaan (planning), permodelan (modelling), konstruksi (construction), serta penyerahan sistem ke para pengguna (deployment), yang diakhiri dengan dukungan pada perangkat lunak lengkap yang dihasilkan (Pressman, 2012). Menurut penulis metode ini cukup efektif karena aplikasi yang dihasilkan lebih baik dan berkualitas yang bertujuan membantu dalam memberi kemudahan serta efektivitas pelayanan informasi kepada staff TU, guru, siswa maupun orang tua/wali siswa.

\section{REFERENSI PUSTAKA}

\subsection{Penjelasan Waterfall Methode}

Pengembangan sistem merupakan penyusunan suatu sistem yang baru untuk menggantikan sistem yang lama secara keseluruhan atau memperbaiki sistem yang telah ada. Ada beberapa macam model pengembangan sistem, yaitu model SDLC, Prototipe, RAD dan masih banyak lagi lainnya. 
Fokus penelitiannya yaitu menggunakan model SDLC waterfall yang sering disebut model squensial linier atau alur hidup klasik. Model waterfall menyediakan pendekatan alur hidup perangkat lunak secara skuensial atau terurut dari mulai analisis, design, pengkodean, pengujian, dan tahap pendukung.

Adapun gambaran dari tahapan-tahapan pengembangan sistem ini sebagai berikut:

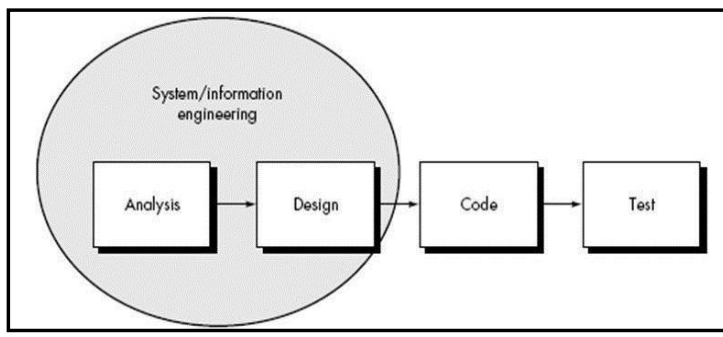

Gambar 1. Ilustrasi Model Waterfall

Adapun tahapan-tahapannya sebagai berikut :

\section{a. Analisis Kebutuhan Sistem Perangkat Lunak}

Proses pengumpulan kebutuhan dilakukan secara intensif untuk menspesifikasikan kebutuhan perangkat lunak agar dapat dipahami perangkat lunak seperti apa yang dibutuhkan oleh user.

\section{b. Desain}

Desain perangkat lunak adalah proses multi langkah yang fokus pada desain pembuatan program perangkat lunak termasuk struktur data, arsitektur perangkat lunak, representasi antarmuka, dan prosedur pengodean. Proses ini mentranslasi kebutuhan perangkat lunak dari tahap analisis kebutuhan ke representasi desain agar dapat diimplementasikan menjadi program pada tahap selanjutnya.

\section{c. Pembuatan Kode Program}

Desain harus ditranslasikan ke dalam program perangkat lunak. Hasil dari tahap ini adalah program komputer sesuai dengan desain yang telah dibuat pada tahap desain.

\section{d. Pengujian}

Pengujian fokus pada perangkat lunak secara dari segi lojik dan fungsional dan memastikan bahwa semua bagian sudah diuji. Hal ini untuk meminimalisir kesalahan (error) dan memastikan keluaran yang dihasilkan sesuai dengan yang diinginkan.

Di dalam tahapan pertama dari metode SDLC yaitu analisis sistem, perlu adanya UML yang berfungsi untuk mempermudah menggambarkan sistem yang akan dibuat.

\subsection{Pengertian Aplikasi}

Menurut Sutabri (2012:147), "Aplikasi adalah alat terapan yang difungsikan secara khusus dan terpadu sesuai kemampuan yang dimilikinya."

Menurut Asropudin (2013:6), "Aplikasi adalah software yang dibuat oleh suatu perusahaan komputer untuk mengerjakan tugastugas tertentu, misalnya Ms.World, Ms.Excel."

"Aplikasi web merupakan halaman dinamis yang mengijinkan interaksi dengan user (user melakukan sesuatu). Interaksi user dengan aplikasi web misalnya user mengklik sebuah tombol dan warna latar belakang web berubah." (M. Shalahudin dan Rosa A.S. 2010:6)

\subsection{Buku Induk Siswa}

Buku induk Siswa adalah kumpulan daftar nama siswa sepanjang masa dari sekolah tersebut. Setiap siswa harus dicatat dalam buku besar yang biasa

disebut bukuinduk siswa ataubukupokok.Catatan dalam buku induk siswa harus lengkap yang meliputi data dan identitas siswa. Data-data tersebut diambil dari formulir pada saat pendaftaran Penerimaan Peserta Didik Baru (PPDB)

Selain dari identitas siswa yang meliputi nama orang tua dll., dalam buku induk juga berisi nomor induk siswa, nomor induk siswa nasional, nomor kode sekolah, keterangan orangtua/wali siswa, dan prestasi belajar siswa (daftar nilai raport) dari tahun ke tahun selama siswa tersebut belajar di sekolah.

\section{HASIL DAN PEMBAHASAN}

\subsection{Metode pengumpulan Data}

Pada penelitian ini penulis menggunakan metode deskriptif, yaitu metode yang menggambarkan suatu keadaan atau permasalahan yang sedang terjadi berdasarkan fakta dan data-data yang diperoleh dan dikumpulkan pada waktu melaksanakan penelitian. Untuk mendapatkan data yang diperlukan dalam penyusunan Laporan 
ini, maka digunakan metode pengumpulan data sebagai berikut, yaitu:

\subsubsection{Observasi /Pengamatan}

Melakukan peninjauan atau pengamatan secara langsung ke lapangan pada SDIT Insan Kamil yang beralamat di Perumahan Graha Asri Kompleks Lavender Desa Simpangan Kecamatan Cikarang Utara, dengan cara mengumpulkan data, informasi, dan mempelajari catatan serta dokumen yang ada. Adapun hasil yang di dapat dari observasi selama 1 (satu) bulan adalah mengetahui sistem yang berjalan khususnya proses pengelolaan buku induk siswa dan tata usaha sebagai pengelola data tersebut.

\subsubsection{Wawancara/Interview}

Selain menggunakan metode observasi, penulis juga menggunakan metode interview atau wawancara, yaitu Melakukan kegiatan tanya jawab dengan peserta didik dan Guru untuk mendapat data-data yang berkaitan dengan penelitian.

\subsubsection{Studi Pustaka/Library Research}

Dilakukan dengan cara mempelajari referensireferensi buku, artikel, dan browsing internet yang berhubungan dengan sistem informasi pemgolahan data siswa berbasis web dengan dukungan framework laravel. Pengumpulan data dengan memanfaatkan daftar pustaka ini adalah agar dapat lebih mendukung objek suatu penelitian dengan melakukan perbandingan teori-teori yang sudah ada dengan praktek yang ada di lokasi sumber data.

\subsection{Kerangka Pemikiran}

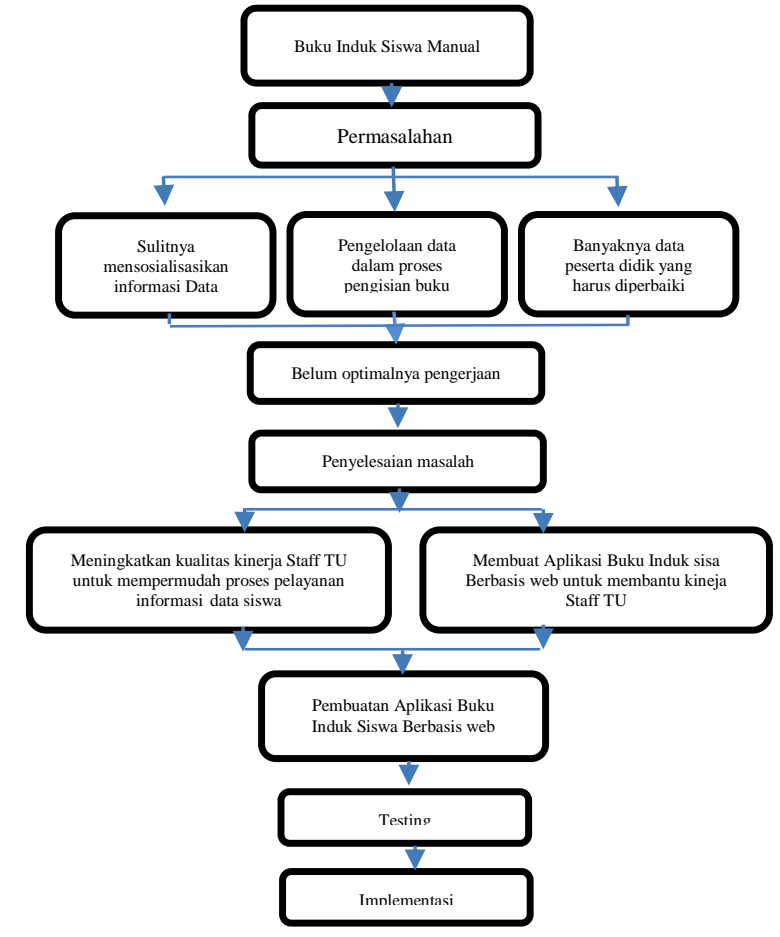

Gambar 2. Kerangka Pemikiran

\subsubsection{Usecase Diagram}

Sebuah use case digunakan untuk menganalisa kebutuhan dari Aplikasi Buku Induk Siswa Berbasis Web di SDIT Insan Kamil yang akan dibuat. Diagram use case juga menunjukkan fungsi fungsionalitas suatu sistem atau kelas dan bagaimana sistem berinteraksi dengan dunia luar. Secara umum pemodelan use case pada aplikasi ini dapat dilihat pada gambar berikut :

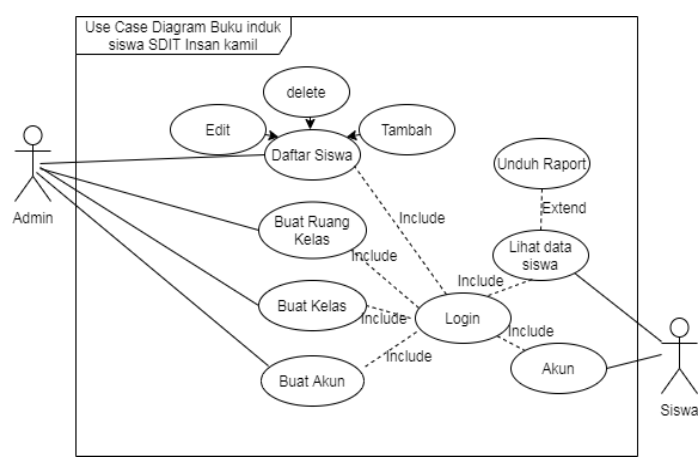

Gambar 3. Usecase Diagram

a. Siswa dapat mengakses informasi melalui web. Siswa dapat login ke web sesudah mendapat akun yang diberikan admin, setelah login berhasil maka akan tampil halaman 
home siswa setelah itu siswa dapat melakukan cek biodata diri dan mealukan pengunduhan Raport.

b. Admin terlebih dahulu melakukan login dengan memasukan nama pengguna dan password. Jika login berhasil maka akan tampil home admin setelah itu admin dapat melakukan megelola data siswa, data kelas, dan mengelola akun.

\subsection{Pembahasan}

\subsubsection{Pengujian Sistem}

Pengujian merupakan bagian yang penting dalam siklus pembangunan perangkat lunak. Pengujian dilakukan untuk menjamin kualitas dan juga mengetahui kelemahan dari perangkat lunak. Tujuan dari pengujian adalah menjamin bahwa perangkat lunak yang dibangun memiliki kualitas yang handal yaitu mampu mempretasikan kajian pokok dari spesifikasi, analisis, perancangan dan pengkodean dari perangkat lunak itu sendiri.

Adapun kriteria pengujian tersebut dimaksudkan untuk mengetahui kebenaran perangkat lunak dan kesesuaian dengan spesifikasinya dinyatakan berhasil apabila aplikasi mampu menjalankan fungsi-fungsi berdasarkan spesifikasi secara benar. Sebaliknya pengujian dinyatakan gagal jika terdapat fungsi dari perangkat lunak dalam spesufukasi yang tidak dapat dijalankan dalam proses pengujian. Pengujian perangkat lunak ini menggunakan metode pengujian Blackbox. Pengujian blackbox berfokus pada persyaratan fungsional perangkat lunak yang dibuat.

\section{Rencana Pengujian}

Pencana pengujian yang akan dilakukan dengan menguji sistem. Pengujian Aplikasi Buku Induk Suswa berbasis Web berikut menggunakan data uji berupa masukan dari admin dan peserta. Rencana pengujian selengkapnya terlihat pada tabel dibawah ini :

Tabel 1. Rencana Pengujian

\begin{tabular}{|l|l|c|}
\hline \multicolumn{3}{|c|}{ Rencana Pengujian } \\
\hline Kelas Uji & Detail Pengujian & $\begin{array}{c}\text { Jenis } \\
\text { Pengujian }\end{array}$ \\
\hline $\begin{array}{l}\text { Login } \\
\text { Admin }\end{array}$ & Verifikasi data & Black Box \\
& $\begin{array}{l}\text { login admin } \\
\text { dengan }\end{array}$ & \\
& memasukan & \\
& usename dan & \\
\hline
\end{tabular}

\begin{tabular}{|c|c|c|}
\hline & password & \\
\hline $\begin{array}{l}\text { Pengujian } \\
\text { Registrasi } \\
\text { Akun } \\
\text { Siswa }\end{array}$ & $\begin{array}{l}\text { Proses mengisi } \\
\text { Form akun untuk } \\
\text { hak akses siswa } \\
\text { dengan mengisi } \\
\text { email username } \\
\text { dan password }\end{array}$ & Black Box \\
\hline $\begin{array}{l}\text { Pengujian } \\
\text { input } \\
\text { Biodata } \\
\text { Siswa }\end{array}$ & $\begin{array}{l}\text { Proses input } \\
\text { biodata sisswa } \\
\text { sekaligus proses } \\
\text { simpan dilakukan } \\
\text { oleh admin }\end{array}$ & Black Box \\
\hline $\begin{array}{l}\text { Pengujian } \\
\text { melihat } \\
\text { profil siswa } \\
\text { dan } \\
\text { mengunduh } \\
\text { raport }\end{array}$ & $\begin{array}{l}\text { Proses melihat } \\
\text { data diri masing } \\
\text { masing siswa dan } \\
\text { mengunduh } \\
\text { raport yang } \\
\text { dilakukan oleh } \\
\text { siswa }\end{array}$ & Black Box \\
\hline
\end{tabular}

\section{Kasus dan Hasil Pengujian}

Pengujian perangkat lunak ini dilakukan pada modul modul yang ada pada aplikasi PPDB berbasis web maka dapat dilakukan pengujian sebagai berikut:

\section{a. Pengujian Login}

Tabel 2. Pengujian Login

\begin{tabular}{|c|c|c|c|}
\hline \multicolumn{4}{|c|}{$\begin{array}{c}\text { Pengujian Login Admin Kasus dan Uji Login } \\
\text { Admin (Data Normal) }\end{array}$} \\
\hline $\begin{array}{l}\text { Data } \\
\text { Masukan }\end{array}$ & $\begin{array}{l}\text { Yang } \\
\text { diharapkan }\end{array}$ & $\begin{array}{l}\text { Pengama } \\
\text { tan }\end{array}$ & $\begin{array}{l}\mathrm{K} \\
\text { esimpu } \\
\text { lan }\end{array}$ \\
\hline $\begin{array}{l}\text { Username } \\
\text { dan } \\
\text { password } \\
\text { yang di } \\
\text { masukan } \\
\text { benar } \\
\text { (valid) }\end{array}$ & $\begin{array}{l}\text { Dapat } \\
\text { masuk ke } \\
\text { halaman } \\
\text { utama } \\
\text { admin }\end{array}$ & $\begin{array}{l}\text { Usernam } \\
\text { e dan } \\
\text { password } \\
\text { sesuai } \\
\text { Menampi } \\
\text { lkan } \\
\text { menu } \\
\text { utama } \\
\text { admin }\end{array}$ & $\begin{array}{l}{[\sqrt{ }]} \\
\text { diterim } \\
\text { a } \\
{[]} \\
\text { ditolak }\end{array}$ \\
\hline \multicolumn{4}{|c|}{$\begin{array}{l}\text { Pengujian Login Admin Kasus dan Uji Login } \\
\text { Admin (Data salah) }\end{array}$} \\
\hline $\begin{array}{l}\text { Data } \\
\text { Masukan }\end{array}$ & $\begin{array}{l}\text { Yang } \\
\text { diharapkan }\end{array}$ & $\begin{array}{l}\text { Pengam } \\
\text { atan }\end{array}$ & $\begin{array}{l}\text { Kesimp } \\
\text { ulan }\end{array}$ \\
\hline $\begin{array}{l}\text { Username } \\
\text { dan } \\
\text { password } \\
\text { yang di }\end{array}$ & $\begin{array}{l}\text { Tidak dapat } \\
\text { masuk ke } \\
\text { halaman } \\
\text { utama }\end{array}$ & $\begin{array}{l}\text { Userna } \\
\text { me dn } \\
\text { passwor } \\
\text { d tidak }\end{array}$ & $\begin{array}{l}\sqrt{ }] \\
\text { diterima } \\
{[]} \\
\text { ditolak }\end{array}$ \\
\hline
\end{tabular}




\begin{tabular}{|l|l|l|l|}
\hline masukan & admin dan & sesuai & \\
salah & tampilkan & & \\
(tidak & pesan & & \\
valid) & usename & & \\
& dan & & \\
& password & & \\
& salah & & \\
\hline
\end{tabular}

\section{b. Pengujian Registrasi Akun}

Tabel 3. Pengujian Registrasi Akun

\begin{tabular}{|c|c|c|c|}
\hline \multicolumn{4}{|c|}{ Pengujian Registrasi Akun(Data Normal) } \\
\hline $\begin{array}{l}\text { Data } \\
\text { Masukan }\end{array}$ & $\begin{array}{l}\text { Yang } \\
\text { diharapk } \\
\text { an }\end{array}$ & $\begin{array}{l}\text { Pengama } \\
\text { tan }\end{array}$ & $\begin{array}{l}\text { Kesimpul } \\
\text { an }\end{array}$ \\
\hline $\begin{array}{l}\text { Klik } \\
\text { Menu } \\
\text { User }\end{array}$ & $\begin{array}{l}\text { Dapat } \\
\text { masuk } \\
\text { ke } \\
\text { halaman } \\
\text { User }\end{array}$ & $\begin{array}{l}\text { Melihat } \\
\text { menu } \\
\text { User }\end{array}$ & $\begin{array}{l}{[\sqrt{ }]} \\
\text { diterima } \\
\text { [ ] ditolak }\end{array}$ \\
\hline $\begin{array}{l}\text { Klik Add } \\
\text { User }\end{array}$ & $\begin{array}{l}\text { Dapat } \\
\text { masuk } \\
\text { ke Form } \\
\text { Registras } \\
\text { i }\end{array}$ & $\begin{array}{l}\text { Melihat } \\
\text { isi Form } \\
\text { Registras } \\
\text { i }\end{array}$ & $\begin{array}{l}{[\sqrt{ }]} \\
\text { diterima } \\
{[] \text { ditolak }}\end{array}$ \\
\hline $\begin{array}{l}\text { Klik } \\
\text { tombol } \\
\text { Registrasi }\end{array}$ & $\begin{array}{l}\text { Data } \\
\text { Registras } \\
\text { i } \\
\text { tersimpa } \\
\text { n di } \\
\text { database }\end{array}$ & $\begin{array}{l}\text { Muncul } \\
\text { pesan } \\
\text { User } \\
\text { berhasil } \\
\text { ditambah } \\
\text { kan }\end{array}$ & $\begin{array}{l}{[\sqrt{ }]} \\
\text { diterima } \\
\text { [ ] ditolak }\end{array}$ \\
\hline
\end{tabular}

\section{c. Pengujian Input Biodata}

Tabel 4. Pengujian Input Biodata

\begin{tabular}{|c|c|c|c|}
\hline \multicolumn{4}{|c|}{ Pengujian Input Biodata (Data Normal) } \\
\hline $\begin{array}{l}\text { Data } \\
\text { Masuk } \\
\text { an }\end{array}$ & $\begin{array}{l}\text { Yang } \\
\text { diharapk } \\
\text { an }\end{array}$ & Pengamatan & $\begin{array}{l}\text { Kesimpu } \\
\text { lan }\end{array}$ \\
\hline $\begin{array}{l}\text { Klik } \\
\text { Menu } \\
\text { Berand } \\
\text { a }\end{array}$ & $\begin{array}{l}\text { Dapat } \\
\text { masuk } \\
\text { ke } \\
\text { halaman } \\
\text { Beranda }\end{array}$ & $\begin{array}{l}\text { Melihat } \\
\text { menu } \\
\text { Beranda }\end{array}$ & $\begin{array}{l}{[\sqrt{ }]} \\
\text { diterima } \\
{[]} \\
\text { ditolak }\end{array}$ \\
\hline $\begin{array}{l}\text { Userna } \\
\text { me dan } \\
\text { passwo } \\
\text { rd } \\
\text { yang } \\
\text { di } \\
\text { masuk } \\
\text { an } \\
\text { benar }\end{array}$ & $\begin{array}{l}\text { Dapat } \\
\text { masuk } \\
\text { ke } \\
\text { halaman } \\
\text { utama } \\
\text { admin }\end{array}$ & $\begin{array}{l}\text { Username } \\
\text { dan } \\
\text { password } \\
\text { sesuai } \\
\text { Menampilk } \\
\text { an menu } \\
\text { utama } \\
\text { peserta }\end{array}$ & $\begin{array}{l}{[\sqrt{ }]} \\
\text { diterima } \\
{[]} \\
\text { ditolak }\end{array}$ \\
\hline
\end{tabular}

\begin{tabular}{|l|l|l|l|}
\hline (valid) & & & \\
\hline $\begin{array}{l}\text { Klik } \\
\text { tombol } \\
\text { add } \\
\text { siswa }\end{array}$ & $\begin{array}{l}\text { Masuk } \\
\text { ke } \\
\text { halaman } \\
\text { form } \\
\text { biodata } \\
\text { dan } \\
\text { menginp } \\
\text { ut } \\
\text { biodata }\end{array}$ & $\begin{array}{l}\text { Melihat } \\
\text { form } \\
\text { biodata }\end{array}$ & $\begin{array}{l}{[\sqrt{ }]} \\
\text { diterima } \\
{[]} \\
\text { ditolak }\end{array}$ \\
\hline $\begin{array}{l}\text { Klik } \\
\text { tombol } \\
\text { submit }\end{array}$ & $\begin{array}{l}\text { Biodata } \\
\text { masuk } \\
\text { ke } \\
\text { database }\end{array}$ & $\begin{array}{l}\text { Biodata } \\
\text { berhasil di } \\
\text { simpan }\end{array}$ & $\begin{array}{l}{[\sqrt{ }]} \\
\text { diterima } \\
{[]} \\
\text { ditolak }\end{array}$ \\
\hline
\end{tabular}

\section{d. Pengujian Lihat Profil dan Unduh Raport}

Tabel 5. Pengujian Lihat Profil dan Unduh Raport

Pengujian Lihat Profil dan Unduh Raport (Data Normal)

\begin{tabular}{|l|l|l|l|}
\hline \multicolumn{1}{|c|}{$\begin{array}{c}\text { Data } \\
\text { Masukan }\end{array}$} & $\begin{array}{l}\text { Yang } \\
\text { diharapka } \\
\mathrm{n}\end{array}$ & $\begin{array}{l}\text { Pengamata } \\
\mathrm{n}\end{array}$ & $\begin{array}{l}\text { Kesimp } \\
\text { ulan }\end{array}$ \\
\hline $\begin{array}{l}\text { Klik } \\
\text { Menu } \\
\text { Beranda }\end{array}$ & $\begin{array}{l}\text { Dapat } \\
\text { masuk ke } \\
\text { halaman } \\
\text { Beranda }\end{array}$ & $\begin{array}{l}\text { Melihat } \\
\text { menu } \\
\text { Beranda }\end{array}$ & $\begin{array}{l}{[\sqrt{ }]} \\
\text { diterim } \\
\mathrm{a} \\
{[]} \\
\text { ditolak }\end{array}$ \\
\hline $\begin{array}{l}\text { Usernam } \\
\text { e dan } \\
\text { passwor } \\
\text { d yang } \\
\text { di } \\
\text { masukan } \\
\text { benar } \\
\text { (valid) }\end{array}$ & $\begin{array}{l}\text { Dapat } \\
\text { masuk ke } \\
\text { halaman } \\
\text { utama } \\
\text { admin }\end{array}$ & $\begin{array}{l}\text { dasername } \\
\text { password } \\
\text { sesuai } \\
\text { Menampilk } \\
\text { an menu } \\
\text { utama } \\
\text { peserta }\end{array}$ & $\begin{array}{l}{[\sqrt{ }]} \\
\text { diterim } \\
\text { a } \\
{[]} \\
\text { ditolak }\end{array}$ \\
\hline $\begin{array}{l}\text { Klik } \\
\text { tombol } \\
\text { menu } \\
\text { profile }\end{array}$ & $\begin{array}{l}\text { Masuk ke } \\
\text { halaman } \\
\text { profile }\end{array}$ & $\begin{array}{l}\text { Melihat } \\
\text { data diri } \\
\text { siswa }\end{array}$ & $\begin{array}{l}{[\sqrt{ }]} \\
\text { diterim } \\
\text { a } \\
{[]} \\
\text { ditolak }\end{array}$ \\
\hline $\begin{array}{l}\text { Klik } \\
\text { tombol } \\
\text { menu } \\
\text { raport } \\
\text { dan klik } \\
\text { unduh }\end{array}$ & $\begin{array}{l}\text { Masuk ke } \\
\text { halaman } \\
\text { raort }\end{array}$ & $\begin{array}{l}\text { Raport } \\
\text { terunduh }\end{array}$ & $\begin{array}{l}\text { a }] \\
\text { diterim } \\
{[]} \\
\text { ditolak }\end{array}$ \\
\hline
\end{tabular}




\begin{tabular}{|l|l|l|l|}
\hline raport & & & \\
& & & \\
& & & \\
\hline
\end{tabular}

\subsection{Implementasi}

\subsubsection{Dasboard Admin}

Form ini digunakan admin untuk mengelola semua fasilitas yang ada pada aplikasi Buku Induk Siswa.

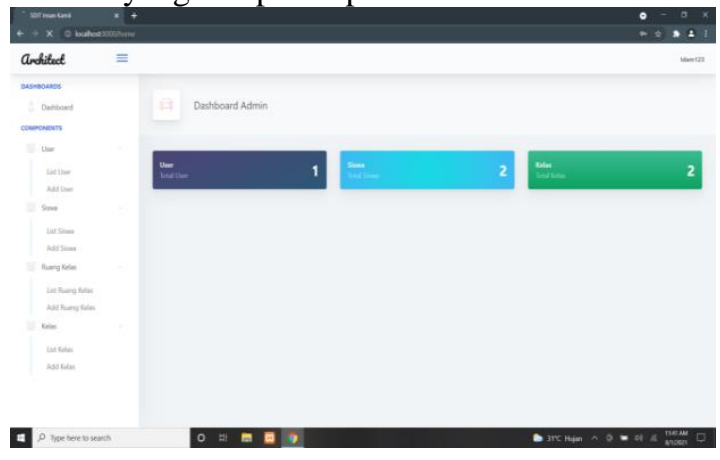

Gambar 3. Dasboard Admin

\subsubsection{Dasboard User}

Form ini digunakan siswa untuk merihat data diri dan mengunduh raport.

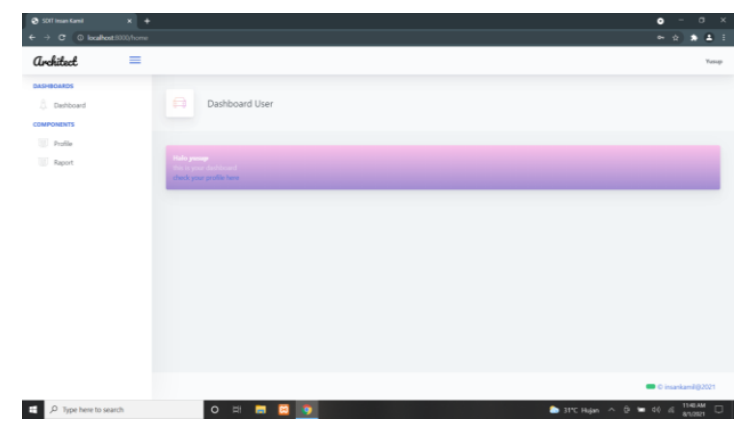

Gambar 4. Dasboard User

\subsubsection{Menu Registrasi}

Tampilan form berikutnya adalah form untuk menambahakan pengguna atau user baru agar dapat masuk di aplikasi Buku Induk Siswa.

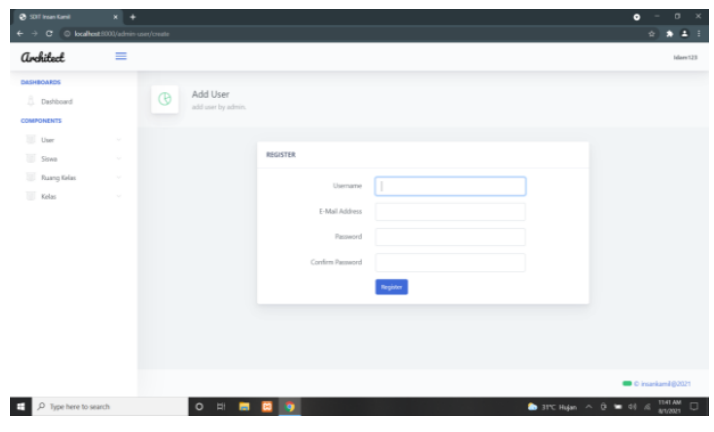

Gambar 5. Tampilan Menu Registrasi

\subsubsection{Menu Siswa}

Menu berikut ini menampilkan data diri siswa dan nilai raport siswa.

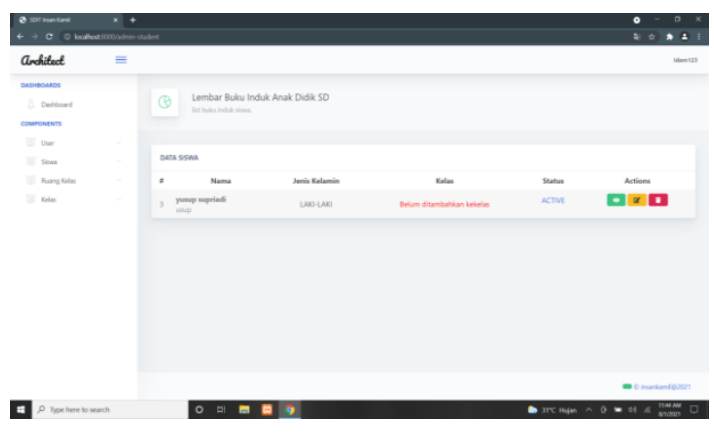

Gambar 6. Tampilan Menu Siswa

\subsubsection{Menu Ruang Kelas}

Menu ini digunakan untuk menambahkan kelas baru dan mengelola kelas yang sudah dibuat.

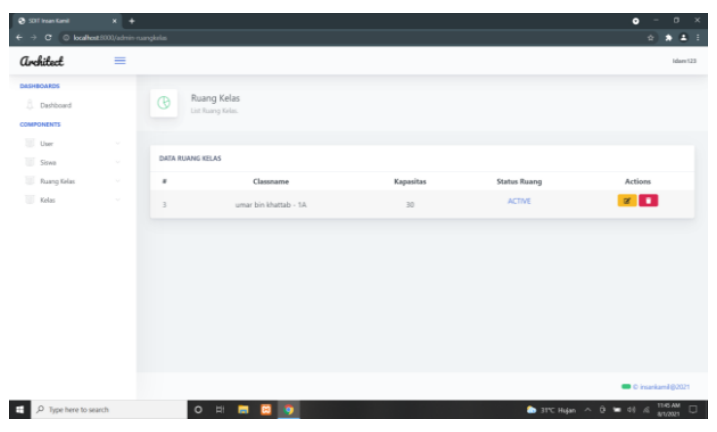

Gambar 7. Halaman Menu Ruang Kelas

\subsubsection{Menu Kelas}

Menu ini digunakan untuk menambahkan siswa kedalam ruang kelas yang sudah dibuat dan menambahkan nilai raport dari siswa tersebut. 


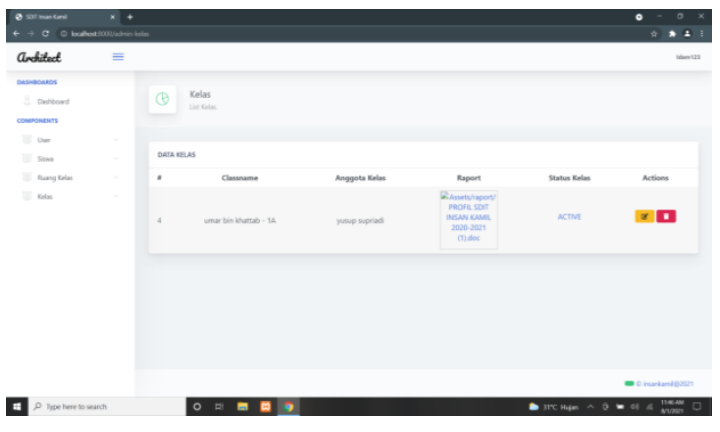

Gambar 8. Tampilan Menu Kelas

\subsubsection{Menu Login}

Menu ini digunakan oleh admin maupun user untuk dapat masuk ke dalam aplikasi Buku Induk Siswa dengan terlebih dahulu mengisikan username dan password.

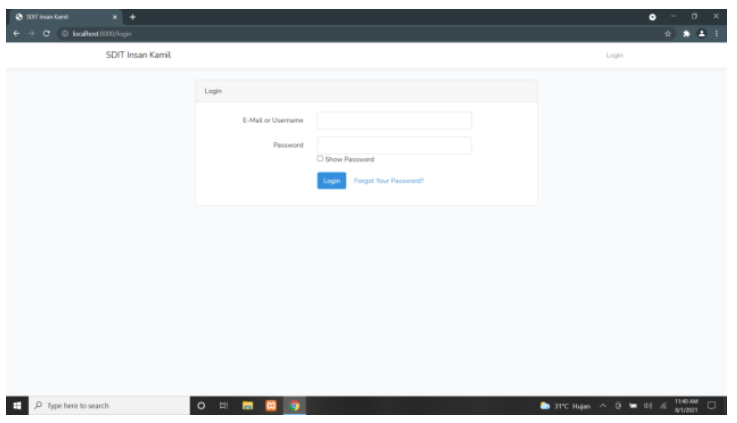

Gambar 9. Tampilan Menu Login

\subsubsection{Halaman Beranda}

Di dalam halaman ini menyajikan profil dari SDIT Insan Kamil serta Visi Misi dan galery poto kegiatan.

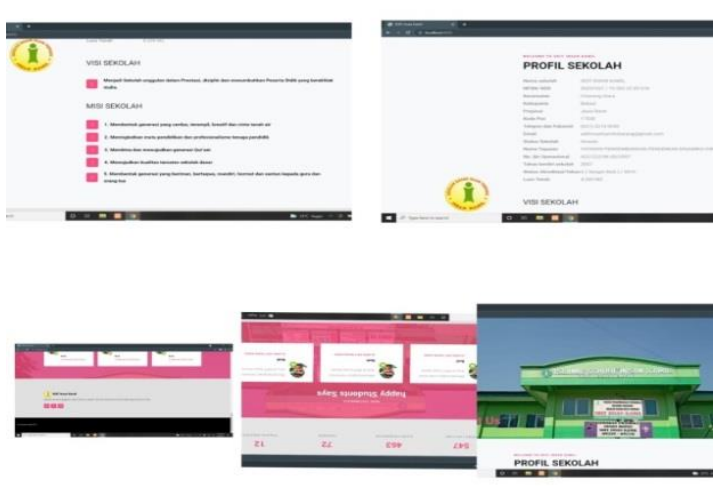

Gambar 10. Halaman Beranda

\subsection{Validasi Penguna Sistem}

Untuk menguji aplikasi atau sistem yang penulis buat ini diterima oleh pengguna, maka penulis melakukasn validasi pengguna sistem dengan uraian sebagai berikut :

\section{Jumlah kuesioner}

Dari jumlah user yang di tentukan yaitu guru, siswa dan admin maka yang dipilih dari guru yang menjadi pengguna, yaitu sebanyak 10 orang namun yang di jadikan responden hanya 5 orang, karena menghemat waktu agar validasi pengguna aplikasi dapat dilakukan dengan cepat tetapi tetap menjaga keakuratanya.

\section{Bentuk Pertanyaan}

Untuk menguji aplikasi Buku Induk Siswa berbasis web ini, maka penulis membuiat pengajuan dalan bentuk pertanyaan yang terdiri dari 3 jenis pertanyaan, yaitu pertanyaan tentang tampilan aplikasi sebanyak 2 pertanyaan, pertanyaan tentang alur sebanyak 2 pertanyaan dan pertanyaan tentang kegunaan aplikasi sebanyak 2 pertanyaan . kemudian di beri 5 pilihan jawaban dengan memnerikan tanda ceklish $(\sqrt{ })$. Adapun pilihan jawaban adalah sebagai berikut :

1. SS (sangat Setuju)

2. S (Setuju)

3. B (Biasa)

4. TS Tidak Setuju)

5. STS (sangat Tidak Setuju)

Tabel 6. Tabel Kuisioner

\begin{tabular}{|c|l|c|c|c|c|c|}
\hline $\begin{array}{l}\text { N } \\
\text { o }\end{array}$ & Pertanyaan & S & S & B & T & S \\
S & T \\
a. & Tampilan Aplikasi & & & & & \\
\hline 1 & $\begin{array}{l}\text { Apakah anda setuju } \\
\text { tampilan aplikasi } \\
\text { menarik dan aktaktif? }\end{array}$ & & & & & \\
\hline 2 & $\begin{array}{l}\text { Apakah anda setuju } \\
\text { jika aplikasi ini sudah } \\
\text { sesuai dengan } \\
\text { kebutuhan? }\end{array}$ & & & & & \\
\hline b. & \multicolumn{1}{|c|}{ Alur Aplikasi } & & & & \\
\hline
\end{tabular}




\begin{tabular}{|c|c|}
\hline 1 & $\begin{array}{l}\text { Apakah anda setuju } \\
\text { jika alur aplikasi ini } \\
\text { jelas dan masuk akal? }\end{array}$ \\
\hline 2 & $\begin{array}{l}\text { Apakah anda setuju } \\
\text { jika alur aplikasi ini } \\
\text { berjalan sesuai } \\
\text { fungsinya? }\end{array}$ \\
\hline c. & Kegunaan Aplikasi \\
\hline 1 & $\begin{array}{l}\text { Apakah anda setuju } \\
\text { aplikasi ini membantu } \\
\text { kinerja guru dan tata } \\
\text { usaha.? }\end{array}$ \\
\hline 2 & $\begin{array}{l}\text { Apakah setuju kalau } \\
\text { aplikasi ini } \\
\text { memberikan layanan } \\
\text { infirmasi yang cepat } \\
\text { dan efektif? }\end{array}$ \\
\hline
\end{tabular}

\section{a. Hasil Pengujian Tampilan Sistem}

Tabel 7. Pengujian Tampilan Sistem

\begin{tabular}{|c|c|c|c|c|}
\hline $\begin{array}{l}N \\
\mathrm{O}\end{array}$ & Pertanyaan & $\begin{array}{c}\text { Jawa } \\
\text { ban }\end{array}$ & $\begin{array}{c}\text { Resp } \\
\text { onden }\end{array}$ & $\begin{array}{c}\text { Pesenta } \\
\text { si } \%\end{array}$ \\
\hline \multirow[t]{5}{*}{1} & \multirow{5}{*}{$\begin{array}{l}\text { Apakah anda } \\
\text { setuju } \\
\text { tampilan } \\
\text { aplikasi } \\
\text { menarik dan } \\
\text { aktaktif? }\end{array}$} & SS & 3 & 60 \\
\hline & & $\mathrm{S}$ & 1 & 20 \\
\hline & & $\mathrm{B}$ & 1 & 20 \\
\hline & & TS & & \\
\hline & & STS & & \\
\hline \multicolumn{3}{|c|}{ Jumlah } & 5 & 100 \\
\hline \multirow[t]{5}{*}{2} & \multirow{5}{*}{$\begin{array}{l}\text { Apakah anda } \\
\text { setuju jika } \\
\text { aplikasi ini } \\
\text { sudah sesuai } \\
\text { dengan } \\
\text { kebutuhan? }\end{array}$} & $\mathrm{SS}$ & 4 & 80 \\
\hline & & $\mathrm{S}$ & 1 & 20 \\
\hline & & $\mathrm{B}$ & & \\
\hline & & $\mathrm{TS}$ & & \\
\hline & & STS & & \\
\hline & Jumlah & & 5 & 100 \\
\hline
\end{tabular}

Berdasarkan table 7 dapat dilihat bahwa pertanyaan pertama yang memilih SS (Sangat Setuju) ada 3 orang denga persentasi $60 \%$ dan memilih $\mathrm{S}$ (setuju) ada 1 orang dengan persentasi $20 \%$, serta yang memilih B (Biasa) 1 orang denga persentasi 20\%, TS( Tidak Setuju), STS (Sangat Tidak Setuju) jumlahnya 0 .Sedangkan untuk pertanyaan kedua yang memilih SS (Sangat Setuju) ada 43 orang denga persentasi $80 \%$ dan memilih S (setuju) ada 1 orang dengan persentasi 20\%,yang memilih B(Biasa), TS ( Tidak Setuju), STS (Sangat Tidak Setuju) jumlahnya 0, jadi total semua responden ada 5 orang dengan jumlah persentasi $100 \%$.

b. Hasil Pengujian Alur Sistem

Tabel 8. Pengujian Alur Sistem

\begin{tabular}{|c|c|c|c|c|}
\hline $\begin{array}{l}\mathrm{N} \\
\mathrm{O}\end{array}$ & Pertanyaan & $\begin{array}{c}\text { Jawab } \\
\text { an }\end{array}$ & $\begin{array}{l}\text { Res } \\
\text { pon } \\
\text { den }\end{array}$ & $\begin{array}{c}\text { Pes } \\
\text { ent } \\
\text { asi } \\
\%\end{array}$ \\
\hline \multirow[t]{5}{*}{1} & \multirow{5}{*}{$\begin{array}{l}\text { Apakah anda } \\
\text { setuju jika alur } \\
\text { aplikasi ini jelas } \\
\text { dan masuk akal? }\end{array}$} & SS & 4 & 80 \\
\hline & & $\mathrm{S}$ & 1 & 20 \\
\hline & & $\mathrm{B}$ & & \\
\hline & & TS & & \\
\hline & & STS & & 100 \\
\hline \multicolumn{3}{|c|}{ Jumlah } & 5 & \\
\hline \multirow[t]{5}{*}{2} & \multirow{5}{*}{$\begin{array}{lr}\text { Apakah } & \text { anda } \\
\text { setuju jika } & \text { alur } \\
\text { aplikasi } & \text { ini } \\
\text { berjalan } & \text { sesuai } \\
\text { fungsinya? } & \\
\end{array}$} & SS & 2 & 40 \\
\hline & & $\mathrm{S}$ & 3 & 60 \\
\hline & & $\mathrm{B}$ & & \\
\hline & & TS & & \\
\hline & & STS & & \\
\hline \multicolumn{3}{|c|}{ Jumlah } & 5 & 100 \\
\hline
\end{tabular}

Berdasarkan table 8 dapat dilihat bahwa pertanyaan pertama yang memilih SS (Sangat Setuju) ada 4 orang dengan persentasi $80 \%$ dan memilih S (setuju) ada 1 orang dengan persentasi $20 \%$, serta yang memilih B (Biasa), TS( Tidak Setuju), STS (Sangat Tidak Setuju) jumlahnya 0 .Sedangkan untuk pertanyaan kedua yang memilih SS (Sangat Setuju) ada 2 orang denga persentasi $40 \%$ dan memilih $\mathrm{S}$ (setuju) ada 3 orang dengan persentasi $60 \%$,yang memilih B(Biasa), TS ( Tidak Setuju), STS (Sangat Tidak Setuju) jumlahnya 0 , jadi total semua responden ada 5 orang dengan jumlah persentasi $100 \%$.

\section{c. Hasil Pengujian Kegunaan Sistem}

Tabel 9. Pengujian Kegunaan Sistem

\begin{tabular}{|c|c|c|c|c|}
\hline $\begin{array}{l}N \\
0\end{array}$ & Pertanyaan & $\begin{array}{c}\text { Jaw } \\
\text { aba } \\
\mathrm{n}\end{array}$ & $\begin{array}{l}\text { Res } \\
\text { pon } \\
\text { den }\end{array}$ & $\begin{array}{c}\text { Pre } \\
\text { sent } \\
\text { asi } \\
\%\end{array}$ \\
\hline \multirow[t]{5}{*}{1} & \multirow{5}{*}{$\begin{array}{l}\text { Apakah anda setuju } \\
\text { aplikasi ini } \\
\text { membantu kinerja } \\
\text { guru dan tata usaha } \\
?\end{array}$} & SS & 4 & 80 \\
\hline & & $\mathrm{S}$ & 1 & 20 \\
\hline & & B & & \\
\hline & & $\mathrm{TS}$ & & \\
\hline & & $\begin{array}{c}\text { ST } \\
\text { S }\end{array}$ & & 100 \\
\hline \multicolumn{3}{|c|}{ Jumlah } & 5 & \\
\hline \multirow[t]{3}{*}{2} & \multirow{3}{*}{$\begin{array}{l}\text { Apakah setuju } \\
\text { kalau aplikasi ini } \\
\text { memberikan }\end{array}$} & SS & 2 & 40 \\
\hline & & $S$ & 2 & 40 \\
\hline & & B & 1 & 10 \\
\hline
\end{tabular}




\begin{tabular}{|l|l|c|c|c|}
\hline layanan infirmasi & TS & & \\
\cline { 2 - 5 } yang cepat dan & ST & & \\
efektif? & S & & \\
\hline \multicolumn{2}{|l|}{ Jumlah } & 5 & 100 \\
\hline
\end{tabular}

Berdasarkan table 9 dapat dilihat bahwa pertanyaan pertama yang memilih SS (Sangat Setuju) ada 4 orang dengan persentasi $80 \%$ dan memilih S (setuju) ada 1 orang dengan persentasi $20 \%$, serta yang memilih B (Biasa), TS( Tidak Setuju), STS (Sangat Tidak Setuju) jumlahnya 0 .Sedangkan untuk pertanyaan kedua yang memilih SS (Sangat Setuju) ada 2 orang denga persentasi $40 \%$ dan memilih $\mathrm{S}$ (setuju) ada 2 orang dengan persentasi $40 \%$,yang memilih B(Biasa) satu orang denga persentasi 20\%, TS ( Tidak Setuju), STS (Sangat Tidak Setuju) jumlahnya 0, jadi total semua responden ada 5 orang dengan jumlah persentasi $100 \%$.

Pengujian dan validasi pengguna yang telah dilakukan merupakan proses yang terdapat dalam Aplikasi Buku Induk Siswa Berbasis Web. Dan setelah dilakukan pengujain dan validasi dari semua unsur seperti tampilan sistem, alur sistem, dan kegunaan sistem, dengan rata rata memilih SS(Sangat Setuju) dengan persentasi $50 \%$ dan memilih S (setuju) $40 \%$ serta memilih B(biasa) $10 \%$ sedangkat sisanya 0 maka berdasarkan hasil dapat diambil kesimpulan bahwa aplikasi ini layak dan dapat digunakan dengan baik, serta semua yang dilakukan dalam pengujian atau validasi ini diharapkan dapat mewakili pengujian validasi dan fungsi yang lain dalam Aplikasi Buku Induk Siswa Berbasis Web, sehingga aplikasi ini dapat digunakan dan bermanfaat bagi penulis khususnya dan bagi pengguna pada umumnya.

\section{KESIMPULAN}

Berdasarkan analisis, perancangan yang telah dilakukan dalam pembuatan aplikasi Buku Induk Siswa berbasis web ini maka dapat diambil beberapa kesimpulan sebagai berikut:

1. Aplikasi Buku induk siswa ini dapat mengatasi pengolahan data master peserta didik menjadi lebih baik karena disimpan dalam suatu basis data yang terintegrasi serta proses administrasi Buku Induk Siswa menjadi lebih efektif dan efisisen sehingga memberi kemudahan bagi Staff TU di SDIT Insan Kamil

2. Penerapan metode Waterfall yang digunakan untuk metode pengembngan sistem telah dilakukan sesuai dengan yang diharapkan.

3. Aplikasi Buku Induk Siswa berbasis Web dari hasil penelitian ini dapat memberikan kemudahan akses informasi bagi siswa, guru dan orang tua/wali siswa.

\section{DAFTAR PUSTAKA}

[1] A.S Rosa \& M. Shalahuddin. (2016)Rekayasa Perangkat Lunak Berorientasi Objek 2016. Bandung: Informatika.

[2] Arief \& M.Rudyanto. (2013). Pemrograman Web Dinamis Menggunakan PHP dan $M y S Q L$. Yogyakarta: Adni.

[3] Muhammad Solahudin. (2021).RANCANG BANGUN SISTEM INFORMASI AKADEMIK SEKOLAH(SIAS) BERBASIS WEBSITE. Jurnal Komputer dan Teknologi Informasi Volume 4 No.2, Februari 2021. ISSN : 2579-5317.

[4] Naista David. (2017). Codeigniter Vs Laravel. Yogyakarta: Lokomedia.

[5] Tri Sandhika Jaya \& Dwirgo Sahlinal. (2017).PERANCANGAN KANTOR DIGITAL BERBASIS WEB FRAMEWORK DENGAN METODE WATERFALL PADA POLITEKNIK NEGERI LAMPUNG. Jurnal Pengembangan IT DINAMIK Volume 02, No.2, Juli 2017 : ISSN : 2477-5126.

[6] A.S Rosa dan M.Shalahudin. (2010). JAVA $D I W E B$. Bandung: Informatika

[7] I Gusti Lanang Putu Sumiantara, I Made Ardwi Pradnyana, \& Ketut Agustini. (2019).PENGEMBANGAN SISTEM INFORMASI AKADEMIK (SIAK) BERBASIS WEB PADA SEKOLAH TINGGI KEJURUAN DAN ILMU PENDIDIKAN (STKIP) AGAMA HINDU SINGAJAYA. Jurnal Pendidikan Teknologi dan Kejuruan : Jurnal Logic ISSN: 2541-0652.

[8] Ahmadi \& Hermawan. (2013).E-BUSINESS \& E-COMMERCE. Yogyakarta : Andi. 
[9] Madcoms. (2012).ADOBE DREAMWEAVER CS6 DAN PHP UNTUK PEMULA. Yogyakarta: CV Andi Offset..

[10] Sutabri \& Tata. (2012). ANALISA SISTEM INFORMASI. Yogyakarta : Andi. 